\title{
Production Regimes and Class Compromise among European Warehouse
}

\section{Workers}

Nadja Doerflinger, Valeria Pulignano and Steven P. Vallas

(authors are listed in alphabetical order as they equally contributed to the paper)

Accepted for Publication in Work \& Occupations

\section{Authors:}

Valeria Pulignano

Centre for Sociological Research, Faculty of Social Sciences, KU Leuven

Parkstraat 45 bus 3601, 3000 Leuven, Belgium

valeria.pulignano@kuleuven.be

[Corresponding Author]

Nadja Dörflinger

Federal Institute for Occupational Safety and Health (BAuA) Research Group "Changing

World of Work"

Doerflinger.Nadja@baua.bund.de

Steven P. Vallas

College of Social Sciences and Humanities, Northeastern University

958 Renaissance Park

360 Huntington Avenue

Boston, MA 02115, USA

s.vallas@northeastern.edu 


\section{Author biographies:}

Nadja Dörflinger is a senior scientist in the Research Group 'Changing World of Work' at Germany's Federal Institute for Occupational Safety and Health. Her mostly comparative research focuses primarily on labour market segmentation and fragmentation, as well as flexibility and security in European labour markets.

Valeria Pulignano is Professor of Sociology at KULeuven, Belgium. Her research is comparative and it focuses on labour market institutions, flexibility, and employment systems and their impact on job quality, inequality, workers' voice. She is granted a recent ERC AdvancedGrant (ResPecTMe) studying precariousness in digital, creative, and care workplaces.

Steven Vallas is Professor of Sociology at Northeastern University, Boston. Most of his research concerns the transformation of work, struggles over new technologies, and responses to the demands of the new economy. He is currently at work on an NSF-funded study of the algorithmic workplace, as found in various parts of the platform economy.

\section{Acknowledgment}

We are grateful to the editor and the reviewers for the insightful comments on an earlier version of this paper. This research was developed in the framework of three interlinked research projects financed by the Flemish Research Council FWO [project number G071716N]; KU Leuven C1 grant [number C14/16/015] and ResPecTMe by the European Research Council (ERC) under the European Union's Horizon 2020 research and innovation programme [grant agreement number 833577]. 


\begin{abstract}
The orderly functioning of global capitalism increasingly depends on the labor of logistics workers. But social scientists have yet to produce nuanced accounts of the labor process in the many ports, warehouses, and distribution centers that lie at the heart of logistics work. In this study we seek to connect the nascent field of critical logistics studies to theories of the labor process in an effort to understand the production regimes that arise in warehouse work under different economic and regulatory conditions. Using qualitative data gathered at four European warehouses owned by the same third party logistics firm, we identify several distinct types of production regimes at these warehouses and analyze the conditions accounting for each. Even in this globally oriented industry in which firms seek to standardize their international operations, locally rooted conditions play a significant role, generating sharply different forms of labor control even within the same firm.
\end{abstract}

Key words: logistics, production regime, class compromise, warehouses, labor process

In recent years scholars have begun to recognize the importance of the "logistics revolution" for the global circulation of commodities, and thus for the continuation of advanced capitalism as a whole (Bonacich \& Wilson, 2008; Cowen, 2014; Chua, 2014; Lichtenstein, 2009; Sowers, 2017). One theme that has repeatedly surfaced in this literature concerns the furtive power that logistics workers possess (Neilson, 2012). Since workers are employed at the critical "choke points" (Alimahomed-Wilson \& Ness, 2018) of global capitalism, they enjoy latent powers of disruption (Huke et al., 2015) and could bring the circulation of commodities to a screeching halt. Such structural power occasionally surfaces when strikes or job actions occur at strategically important logistics hubs, imposing massive costs on both shippers and logistics firms alike. Although it is easy to flag dramatic instances in which port, warehouse, and 
delivery workers engaged in such actions (Chua, 2014; Benvegnú et al., 2018; Cillo \& Pradella, 2018; Cini \& Tassinari, 2018), scholarly work suggests that instances of struggle are actually quite rare (Alimahomed-Wilson \& Ness, 2018). This raises the question as to why. What mechanisms account for capital's ability to limit logistics workers' structural power? Put differently, how is class dominance maintained within the logistics industry's many ports, warehouses, and shipping networks? Asking these questions means identifying a weakness in the emerging literature on logistics workers: its failure to explore the production regimes that exist within logistics workplaces, through which companies seek to govern the labor processes on which they rely.

In this paper we draw on fieldwork conducted in four warehouses owned and operated by one of the world's largest third-party logistics (3PL) firms. The warehouses are located in three Northern European nations - Belgium, Germany, and the Netherlands - and conduct business-to-business operations, utilizing much the same system of lean management. Yet different production regimes have unfolded at each site, introducing variations which we seek to characterize and explain. The goal of the paper is thus to bring critical logistics studies (Cowen, 2014; Chua et al., 2018) into dialogue with labor process theory, in so doing developing deeper and more work-centred accounts of logistics as a critical branch of global capitalism.

Previous efforts to address the question of labor control among logistics workers have tended to adopt one of two approaches. The first has emphasized the many sources of division that have plagued the logistics workforce, depriving workers of the solidarity needed to transform structural power into working class struggle, mobilization and contestation (Haidinger et al., 2014). Here scholars have pointed to geographic and organizational divisions (Holst \& Singe, 2017; Selwyn, 2012) as well as social divisions based on ethnicity and/or employment status among the logistics workforce itself (Basso, 2015; Bonacich \& Wilson, 
2008). Drawing on this path, scholars who have examined the working conditions and management-labor-relations in logistics have argued that such divisions leave workers unable to contest management's control (Newsome et al., 2013), leaving them subject to managerial despotism (Sainato, 2020). But these studies have mainly focused on liberal market economies, such as the US and Britain (e.g. Newsome, 2010; Sowers et al., 2018), where trade unions suffer from weak bargaining power and neoliberal policies are most pronounced. Omitted in such literature are questions about the varying forms that managerial control over logistics workers assumes in different regions of the global economy, where labor market institutions and state intervention have developed along presumably divergent paths (Hall and Soskice, 2001; Hancke et al., 2007). ${ }^{1}$

A second approach, an outgrowth of research on lean production, has emphasized the technocratic rationality that logistics practices and discourses often impose, in which logistics firms use technologies of control in both the Foucauldian and engineering meanings of the term. Because firms now deploy powerful information and communications systems to govern the flow of goods through global supply chains, including algorithms, sensory equipment, robotics, and artificial intelligence, the performance of each node in the logistics system can be more fully surveilled, directed, and evaluated than ever before (Cowen, 2014; LeCavalier, 2016). The argument here is that neo-Taylorist forms of work organization acquire a power and momentum that are difficult for semi- or unskilled workers to contest, especially where turnover levels -itself a predictable response to unrewarding work — are relatively high.

Although these approaches capture important facets of labor control within the logistics sector, we argue that they provide only a partial understanding of the forces that account for

\footnotetext{
${ }^{1}$ Questions about divisons or fissures among workers have been much theorized in recent years (Weil, 2014). Some theorists see disparities among workers as a shared feature of all advanced capitalist societies ("converging divergences"; see Katz \& Darbishire, 2000). Others speak of growing economic dualism, as some strata of the workforce enjoy greater levels of protection against market-based risks than others (Palier \& Thelen, 2010; Rueda 2014; Doellgast, Lillie \& Pulignano 2018). Most of these studies are couched at a substantial distance from concrete work situations at the establishment level, however, our major concern here.
} 
such control on this terrain. A fuller explanation must address the institutional, market-based and organizational forces that impinge on the labor process and account for the varying levels of workers' power and forms of class compromise that emerge at the point of production itself. We develop this argument by building on theoretical work deriving from the labor process tradition (Burawoy, 1985; Burawoy \& Wright, 1990; Wright, 2000). Workers' behavior is not only influenced by their predetermined interests and/or willingness to resist capital but also by the distinctive political, economic, and institutional contexts that shape their work situations and orientations toward management, and these must be taken into account (Bélanger \& Edwards, 2007).

Using qualitative methods, we scrutinize the conditions that impinge on the social relations in production, focusing in particular on the production regimes that management uses to control the labor process at four warehouses operating under different institutional conditions. Though all these warehouses are owned and managed by the same multinational 3PL firm, and all use the same lean management system, we find substantial variations in the production regimes that obtain, generating distinct types of class compromise, the roots of which we try to unpack. Once institutionalized, these locally rooted production regimes establish limits on workers' capacity to resist, thereby ensuring the firm's ability to control the deployment of labor in accordance with its own needs.

Based on the empirical data, we introduce a typology of production regimes, and trace these types to the different institutional, market-based and organisational forces that obtained at each site. Our typology is meant to capture the varying ways in which management pursues an imperative which is a vital feature of logistics work generally: the pursuit of flexible operations, whether functionally or numerically, which requires that the firm vary its deployment of labor in spite of sharp variations in market demand (Vallas, 1999). Our findings indicate that management's pursuit of flexibility assumes sharply distinct forms, in accordance 
with the local conditions in which each establishment operates. Under the regime we call coercive flexibility, workers enjoy relatively little institutional or market power, and thus have few resources with which to contest management's imposition of scheduling flexibility on its workforce. Here, management finds it possible to externalize the risks it faces, demanding that workers accept working hours and schedules that vary from week to week and even day to day. Under hegemonic flexibility, where workers enjoy somewhat greater power resources, management must negotiate workers' consent to market fluctuations, doing so by offering the equivalent of internal labor markets and the security they can offer aspiring workers. Finally, under institutional mutuality, where workers enjoy significant levels of institutional and market power, management finds it necessary to operate under conditions that define the establishment's operations as requiring reciprocal sacrifices from both sides, in effect approximating what Wright (2000) termed a "positive class compromise". An important task which we address below concerns the conditions that account for these variations, as explained further below.

We develop this argument in the following way. In the next section we sketch the theoretical framework we bring to bear on the warehouses at issue while situating the analysis within the global logistics industry. We then explain the research methods, providing an overview of the four warehouses, the types of production regimes that we observed, and the conditions of employment that explain their differential emergence. In the discussion and conclusion, finally, we extract what we believe are the most important lessons that emerge from our research, both for critical logistics studies and the labor process tradition. We end with a call for much more research on logistics works, whose strategic role within global capitalism is becoming increasingly clear.

\section{Understanding production regimes}


While theorizing the centrality of production in shaping working-class struggles Burawoy (1985) made a crucial analytical distinction between the labor process, conceived as the coordinated set of activities and relations involved in the transformation of raw materials into useful products, and the political apparatuses of production, understood as the institutions that regulate and shape the struggles at the workplace (cf. Burawoy 1979). The latter encompass what he called the 'politics of production'. Accordingly, a factory (or production) regime refers to the overall political form of production, including both the economic effects of the labor process and the political apparatuses of production. At the broadest level, he distinguishes two types of political apparatuses - 'despotic' versus 'hegemonic' - which vary in accordance with the degree to which they rely on coercion versus consent. Seeking to account for the varying forms that managerial despotism or hegemony assume, Burawoy identified an array of factory regimes that emerged in the wake of the industrial revolution in Great Britain (1985: 88-155). In explaining variations among these types, he placed particular weight on levels of market competition, forms of state intervention, and workers' access to means of subsistence apart from wage labor itself.

Burawoy's theory of factory regimes provides a fruitful and arguably underutilized approach toward variations in production politics (Vallas \& Hill, 2012). The theory is most creative when discussing the varying production regimes that arose under industrial capitalism, where levels of market competition, forms of the welfare state, and the impact of labor organization are acknowledged as forces shaping the factory regimes that arose under different conditions. With respect to contemporary capitalism, however, Burawoy recognized only a single type of regime - one which he called 'hegemonic despotism' (1985: 148-52) - through which globally oriented firms take advantage of workers' dependence upon the sale of their labor power, shaping how workers define their work and class situations. Exposed to the threat 
of off-shoring, global competition, and ongoing bouts of unemployment, workers perceive no alternative but to align their interests with those of the firm.

We believe that Burawoy's theory of production politics requires a more elaborate conception of the production regimes emerging across different spaces within the advanced capitalist world. For example, 'hegemonic despotism' may capture some or even a large proportion of American factory regimes, but it seems a more awkward fit when applied to particular German, Dutch, or Belgian establishments, where social conditions bring forth entirely different regimes than Burawoy detects. Similarly, a number of scholars have sought to provide a more nuanced view of the outcomes that emerge from institutionalized class struggle as it unfolds under the varying conditions that shape advanced capitalist labor processes. In this vein, Wright (2000) has developed a theory of class compromise premised on the notion that the antagonistic interests of capital and labor can generate a multiplicity of outcomes, depending on two factors: the 'associational power' which workers have amassed through the construction of labor unions and collective bargaining institutions, and the 'structural power' that emanates from the economic system itself (as when workers hold strategic locations within the labor process or favourable positions in the labor market). In Wright's view, different forms of class compromise unfold as workers wield varying levels of power. At low and middle levels of worker power, a 'negative' form of class compromise tends to arise, in which workers can only interfere with capitalist interests in keeping wages low or otherwise extracting value from workers' labor power. Yet as working class power rises, a 'positive' class compromise can be reached, in which the stability and productivity that results can serve important functions for both capital and labor alike (cf. Burawoy \& Wright, 1990: 252-56). In a similar vein, Bélanger and Edwards (2007) suggest that whether conflict or cooperation prevails between the two combatants depends on each party's concern for workplace control and the long-term development of productive forces. 
Building on these insights, we explore the nature of the production regimes unfolding in the workplaces under investigation here. Our goal is twofold: first, to characterize the most salient variations in production regimes that have emerged; second, to account for such variations by disentangling the conditions that best account for their emergence at each site. To do this we find it necessary to modify Wright's conceptual approach. We identify three sources of variation, and thus speak of the institutional, market-based, and organizational forces that have impinged on each establishment (Figure 1). Singly and in combination, these forces account for the distinctive features of the production regimes that emerged at the four investigated European warehouses.

[Figure 1 about here]

First, we identify the institutional forces, which involve the resources and capabilities that workers have developed through their trade unions and collective bargaining arrangements. These include not only the direct power of workers' own organizations Wright's associational power - but also their indirect effects (for example, the establishment of employment law and regulatory protections that workers have won over time (Doellgast, Lillie \& Pulignano, 2018). Specific features of national industrial relations systems provide examples of this. For example, Belgium's Ghent system fosters high trade union membership due to unions' role in the compulsory provision of unemployment benefits. Similarly, codetermination in Germany attributes to workers and their representatives (via work councils at company level) the right to actively participate in shaping the work environment together with management. Likewise, sectoral agreements that mandate equal wage levels for permanent and temporary workers (as in the Netherlands) also work to constrain management's practices. To capture the direct and indirect forms of power, we refer to the institutional power that workers can wield at any given establishment. 
Second, we identify the market-based forces at hand. Key here are two considerations, one directly rooted in the labor market and the other more obliquely in product markets. Labor markets are obviously important, as Wright (2000) notes, since the existence of either a shortage or a surplus of labor can have clear effects on the capacity of workers and management to bargain, either formally or informally (Brown, 2008). Thus, in locales where labor supplies are scarce, a labor shortage will tend to empower workers, limiting the discipline, work rules, closeness of supervision, and the production intensity that capital can impose. An example of this point can be found in Sallaz's study of the global call center industry (2019), where advantageous labor market conditions enabled Filipino workers to establish far better conditions of employment than than would otherwise have been the case. The results were sufficiently pronounced as to undermine the competitive position of Indian call centers, enabling Filipino firms to assume positions of centrality in the global business outsourcing field. Beyond such labor market dynamics, however, we expect that product markets too will have their own specific effects. Where the establishment is weakly positioned in relation to its competitors or clients, for example, it will often have to accept relatively disadvantageous economic terms in the form of undesirable contracts with suppliers, clients and customers. The establishment's economic viability itself may be at stake, imposing a disciplining effect on workers quite independently of the labor market. In these ways we expect that the position of the establishment in its product markets will also affect the production regimes it exhibits. The weaker the market position of the establishment, the more pressure workers will feel to limit their demands, as external entities gain control over their livelihoods.

The third dimension we identify involves the organizational forces at play, i.e. the internally rooted capacities that workers can exercise through their leverage over strategic resources such as skill or information within the labor process itself. The strategic resources workers possess are at times based on the technical division of labor, which can accord 
particular work groups distinctive levels of control over the flow of work. At other times, workers' organizational power is based on the force of informal norms and cultural resources that workers have established at work and that can erect enduring limits on the exercise of management's behaviour (Vallas, 2003, 2006). The key point here is that workers' power at times emanates from the internal organization of work in ways that, while influenced by wider institutional or market conditions, cannot be reduced to them.

We see these three sources of variation in production regimes as analytically distinct but interrelated in complex ways (Silver, 2003). For example, the scarcity of jobs within a distinctive (local/regional) labor market can impinge on the ability of workers to enforce the institutional rights that regulatory bodies have established. The presence of a sector-wide bargaining agreement can empower workers within the labor process, enabling them to enforce informally established norms. Schmalz et al. (2018) have made precisely this point, arguing that although the relationship between different power resources is complex, their development and specific combinations are crucial for labor's assertiveness - a point with which we agree. The question, which this paper will address, is two-fold: What types of production regimes have emerged with distinct locales? And what combination of forces helps us account for their emergence?

\section{Connecting at the edges: features of the logistic industry}

Modern business defines logistics as involving "that part of supply chain management that plans, implements, and controls the efficient, effective forward and reverse flow and storage of goods, services and related information between the point of origin and the point of consumption in order to meet customers' requirements" (Council of Logistics Management, 2019). Scholars in the critical logistics genre (Chua et al. 2018) provide a more succinct definition, viewing logistics as constituting "a science of value added through circulatory 
systems" (Cowen, 2014: 4-5). The point is that by optimizing the flow of goods throughout global value chains, businesses can maximize their profits and reduce the uncertainty that would otherwise surround the realization of surplus value (Harvey, 2018). Following the Marxian definition of capital as value in motion, each blockage and slowing down of circulation implies a net loss of value, because 'frozen' capital which is not moving is no longer capital. The logistics function thus enables capital to accelerate the movement of goods to its maximum levels, re-defining their distribution as a source of value in its own right.

Enter the 'logistics revolution' (Bonacich \& Wilson, 2008; Cowen, 2014), which drew on military expertise and the nascent field of supply chain management in ways that greatly extended capital's global reach. Offshoring production requires a smooth-running logistics provision that is flexible and predictable, since goods need to be moved quickly and accurately, at low costs and potentially over long distances, which requires modern information and communication technology that constantly monitors and steers the flow of goods through time and space.

Warehouses are vital links in the logistics chain. Since the late 1990s, companies have increasingly outsourced warehousing to a growing number of third-party logistics providers to cut costs (Allen, 1997). As a result, the 3PL industry in the United States has grown tremendously, roughly doubling in size since 2008, reaching 213 billion US dollars in 2018 (Statista, 2020). Yet, logistics firms have not always enjoyed high rates of return, as the industry is characterized by low profit margins due to the intensity of global competition (BCG, 2016). Furthermore, warehousing is an asset-intense business, as providers often own warehouses which need to be upgraded regularly. In accordance, earnings before interest and taxes in logistics range from $-1 \%$ to $8 \%$, with warehousing located somewhere in between (PwC, 2016). 
The article focuses on four warehouses located in Germany, the Netherlands and Belgium. These neighbouring countries are situated in the heart of Europe and possess highquality logistics infrastructure (e.g. ports, airports, dense rail and highway networks). This infrastructure - in combination with their proximity to a large and affluent consumer base makes them attractive locations. The industry is of major importance in all investigated countries. In Germany, logistics is one of the biggest sectors with more than 1.3 million staff and revenues of nearly 200 billion Euro in 2014 (Zanker, 2018), accounting for about 25\% of overall logistics revenues in Europe (BVL, 2018). The country counts about 62,000 logistics companies (mostly SMEs). About 91,000 employees work in warehouses of which about 20\% are agency workers (Ibidem). In the Netherlands, logistics is a strong growing driver of the economy with a value added of 55 billion euros/year and 813.000 employees in 2012 (Dutch Ministry of Economic Affairs, 2014). Belgian logistics contributes 2.9\% of GDP and 3.3\% of domestic employment by generating 11.9 billion Euro in value added and employing 134,000 full-time equivalents in 2015. However, employment figures show a slight decrease from 2010 onwards (Belgian National Bank, 2017).

The majority of functions in warehouses can be fulfilled by low-skilled (or even unskilled) workers (i.e., pickers and reachers), which is reflected in rather low wages. In Germany, about $25 \%$ of all logistics workers earn an hourly wage of less than 10 Euro which the government officially considers as low wage (Zanker, 2018). Furthermore, atypical forms of employment are widespread, though in ways that vary across national boundaries.

\section{Research design and methods}

LogisticsInc (pseudonym) operates about 500 warehouses in Europe and many more worldwide. Our study focuses on four warehouses (Food-BE in Belgium; Electronics in the Netherlands, and Fashion and Food-DE in Germany) which feature a simple, routinized 
production process. They operate in the business-to-business segment, are similar in terms of the consumer goods they store, are roughly similar in size, employ low-skilled workers and make use of a lean management system (OES for "Operational Excellence System") which aims at standardizing practices and operations globally.

In spite of LogisticsInc's effort to standardize its warehouse operations, there are sharp differences in the way the lean management principles and techniques are implemented locally, generating significant across-site variation regarding two issues. First, OES principles have been subject to direct local negotiation under co-determination law in Germany, and employers in Belgium and the Netherlands must respect workers' information and consultation rights, involving employee representatives on decisions leading to substantial changes in work organization. However, only in Germany do works councils have a veto right on certain issues, enabling them to reject management proposals. This explains why German works councils could avoid individual performance measurement but workers in the Dutch and Belgian warehouses could not. Second, the use of digital technology (e.g. robot-assisted packaging and so-called effibots) is slightly more widespread in the two newest warehouses (Electronics and Fashion). The four warehouses have distinct histories and operate under sharply different institutional, market, and organizational conditions, as we discuss further below. Table 1 provides a schematic view of the four establishments in this study.

[Table 1 about here]

We use a multiple-case study design including four cases for replication and inductive (theory-building) purposes. Case selection is driven by the aim of identifying the types of production regimes that have obtained and the conditions generating each. Replication was carried out in two stages (Yin, 2018). First, we selected an exploratory case that could serve as the point of departure for the study, helping to develop its conceptual framework (Yin, 2018). The selection of the exploratory case was motivated by country choice. We chose Germany 
since we expected the country's decentralized and uncoordinated bargaining system to produce within-country variation regarding the evolving production regimes. The data collected from the exploratory case (dubbed "Food-DE") is also included in the final study because it fostered the development of operational concepts (the labor and product market forces) and provided an interesting counterpoint to a second German site selected thereafter.

In the second stage we included cases that could confirm, disprove and/or extend our reasoning with respect to the institutional, market and organizational conditions identified earlier. This was crucial for developing a preliminary theoretical framework describing the investigated phenomenon i.e. production regimes (Eisenhardt, 1989). We added a second German case ("Fashion"), where labor and product market features differed from the exploratory case, enabling us to trace the sources of variation across the two German cases. We then added a Belgian and Dutch case ("Food-BE" and "Electonics," respectively), helping us make cross-national comparisons between establishments facing distinct institutional and market-based conditions. Here we only selected one case per country as we expect the highly centralized and coordinated Belgian and Dutch bargaining systems to limit within-country variation.

It is important to note that as coordinated market economies, Germany, Belgium and the Netherlands exhibit sharply different institutional features (Hall \& Soskice, 2001). In Belgium, collective bargaining coverage and union density are relatively high (96\% and 54.2\%, respectively in 2015-2016), and this pertains to the logistics sector overall and to Food-BE. By contrast, in the Netherlands, union density is rather low (17.3\% in 2017), in spite of the high collective bargaining coverage rate (78.6\% in 2016). In Electronics, the unionisation rate is even below the Netherland's average. In Germany, the collective bargaining coverage rate (56\% in 2016) and union density (17\% in 2016) are fairly low; the unionisation rate in Fashion is higher compared to Food-DE, but also below national average. Moreover, many (particularly 
small) logistics companies opt out or derogate from sectoral collective agreements (Zanker, 2018). In addition, the labor movement reflects different country-based structures and union traditions, with the separation by religion and associated political beliefs in Belgium and the Netherlands, and the single unified trade union structure with no political affiliation in Germany.

Collecting data happened sequentially. This was beneficial in terms of case selection; some of the aspects which turned up to be relevant for the development of the operational concepts were informed by data collected and identified in the other cases (De Vaus, 2001). For instance, the relevance of the institutional forces evolved along the development of the study's cross-national comparative analysis.

\section{Data sources}

Our data were collected between early 2017 and mid-2019. We began by examining secondary material and interviewing seven officials at international and national union organizations with experience in the industry. This made us approach two leading logistics companies for access. Due to one author's prior experience with LogisticsInc, involving a research project on management views of employee participation, we secured access with this firm. The other company declined to participate in the research. We suspect that our data are biased in the direction of more favorable employment conditions than is true in the 3PL sector at large (a point we return to in the conclusion).

Having agreed to participate, LogisticsInc helped us to identify and get in touch with several high-level managers at the headquarters level. Starting from there, we used referral sampling to identify potentially interesting respondents at different levels. The firm did not influence this process, and indeed managers at particular sites retained the right to decline participation. At the same time, the research team used trade union channels at both the European and country level in the sector to stimulate participation of employee representatives 
and workers. This was crucial as it fostered an atmosphere in which local employee representatives and workers could talk freely.

To understand the firm's operations, strategy and employment policies, we carried out five interviews with executives in LogisticsInc's headquarters. These interviews were helpful in guiding our selection of warehouses and the design of the interview guideline. We conducted preliminary fieldwork at the initial German site, and then chose three warehouses that were fairly comparable in terms of stored goods and staffing levels. Eventually, our sample yielded four sites serving different consumer retailers (two handling food, one handling fashion and another one electronic products).

In each warehouse, we interviewed the site manager (duration 90-120 minutes) and additionally, in Belgium, one human resource manager (this function did not exist in the other warehouses). We did extensive site visits everywhere, which included ethnographic observations of work processes and informal talks with workers, resulting in detailed fieldnotes. We then conducted formal interviews with workers $(n=35)$ where this was possible to gain more detailed insights into how they experience their work and working conditions. The broad selection of respondents was conceptually driven; we chose interviewees likely to provide us with dense and rich information relating to the research questions to be posed. With input from managers and team leaders, we constructed a diverse sample of workers performing different functions, at different levels in the hierarchy, and with different socio-demographic backgrounds, levels of seniority and tenure and types of employment contracts. The sample included workers performing a broad array of functions, including order pickers, reachers, employees in quality control, inventory management as well as team leaders and shift managers. Finally, where management was agreeable, we returned to the warehouses for an additional round of interviews with site manager(s) to discuss our findings and interpretations of the data. Specifically, this was the case for Food-BE (additional interview with the plant 
manager), Electronics (additional interview with the site manager, two team leaders and one regional HR manager), and Fashion (additional phone interview with the new site manager).

This sequential collection process allowed for gathering 'thick' data on the investigated warehouses and their operations. In sum, we conducted 60 formal interviews with executives, union representatives, managers and warehouse workers, enabling us to develop a reasonably detailed understanding of variations evident in the production regime at each site (Table 2). Interviews were mostly carried out in the respondents' native languages (i.e. Dutch, German) or in English (with few managers and foreign workers) and transcribed and (if needed) translated to English. Thus, our data are based on a mix of interviews and observations.

To better understand the broader character of labor and employment relations in the industry more generally, we attended three trade union meetings (two in Belgium, one in Germany) at which representatives of LogisticsInc were also present, as well as the LogisticsInc's 2019 annual shareholder meeting. We prepared detailed fieldnotes based on those meetings.

\section{[Table 2 about here]}

It is important to acknowledge one important limitation in our research: an uneven degree of research access across the sites, which limited the depth of data collection in the German warehouses in particular. In Fashion, the position of the site manager was restaffed several times during the data collection which slowed down arranging interviews. In Food-DE, difficult business conditions led to acrimony between local management and the workers' council, making it difficult to gain that site's full trust and participation. To compensate for this issue, we sought out alternative paths for data collection, such as attending a 2-day trade union sectoral meeting on logistics, which provided the opportunity for a number of informal talks with workers and employee representatives of LogisticsInc, and with regional/sectoral experts familiar with the two German sites. In spite of these issues, we are confident that these data 
enable us to characterize the production regimes in ways that capture their essential traits, especially since regional managers confirmed the thrust of our analysis.

\section{The Research Sites}

Electronics, in the Netherlands, was opened about 10 years ago and is located close to the German and Belgian borders. It is a profitable warehouse in which new technologies are tested before being rolled out to other warehouses. Electronics serves as a European distribution center for a number of Asian and American consumer electronics companies and also handles their spare parts business and customs. Volumes are not always predictable and when seasonal fluctuations occur, they are handled by the relatively young workforce, which consists of equal numbers of permanent and temporary agency workers. Slightly more than half of Electronics' employees are migrant workers from Eastern European countries. Management explains this by the tightness of the local labor market, which makes it increasingly difficult to hire native staff.

Food-DE, our initial site, is more than 30 years old and located in a region which has suffered from the decay of the mining industry, causing high levels of long-term unemployment. Food-DE's workforce is relatively old, since employees were often transferred to this location when other warehouses in the region were closed. Food-DE has two big and several small customers mostly storing packaged food for retail outlets but the site holds a weak position in the local economy. As client firms externalize their uncertainties onto the warehouse, flexibility requirements are high, imposing extreme scheduling uncertainty on workers.

Conversely, Fashion (located near Germany's western border) is less than five years old and located in a logistics business park. Fashion's volumes are relatively predictable; the customer provides a detailed forecast one month in advance and a refined forecast one week in 
advance. According to the site manager, the predictability of volumes facilitates staff planning: "we know what we will do tomorrow and the day after and in two weeks' time; it is easy to plan and foresee which means less complexity." Due to seasonal fluctuations, however, management still requires a certain degree of flexibility from its workforce.

Food-BE is a warehouse with as long a history as Food-DE and which serves customers in much the same retail markets. Similar to Food-DE throughout the last decade, several other warehouses in Belgium were closed and their employees transferred to Food-BE. Therefore, it also has a relatively aged workforce. Food-BE benefits from its strategic location, however, as it sits near several larger Belgian cities and the port of Antwerp. Volumes fluctuate, though not as sharply as at Food-DE, and these fluctuations have to be accommodated by the workforce.

\section{Findings}

LogisticsInc competes with numerous providers for warehousing contracts which usually last 2-5 years. Workers experience uncertainty because although they know that "at the end of the contract we go into a period of renewal negotiation with the customer", they often do not know whether "there will be a renewal at all," according to the European VP.

To increase its competitiveness, LogisticsInc has recently globally implemented an operational excellence strategy called OES ("Operational Excellence System”). At its core, OES is a lean management system characterised by process standardization, the monitoring of the flow of goods in real time and continuous improvement to ensure the prompt solution of any possible problem. Short team meetings are held between team leaders and workers at the beginning of each shift and between the different team leaders every two hours thereafter, faintly resembling kaizen sessions. The aim is to counteract possible delays in the flow of goods and provide weekly evaluations of each employee's performance. The company frames its productivity measurement as a coaching resource and OES allows management to measure 
productivity at the individual level. In particular, standardised and routine tasks (e.g. picking and reaching) are supported by a sophisticated IT-system which monitors the flow of goods in real time. Following a company expert, OES brings "productivity gains of at least five percent" at each establishment, and if individual performance measurement is allowed by local employee representatives, "then we can get around 10\% improvement". However, employee representation systems at the workplace and organizational level play an important role regarding performance measurement. Where worker representatives are integrated into strong consultation and decision-making processes (as is the case in the German system of codetermination), workers and their representatives are empowered to exercise their voice. The German works council could use its veto right to forbid individual performance measurement while this is allowed in Belgium and the Netherlands.

\section{Understanding the variations in production regimes}

In spite of the company's effort to roll out OES on a firm-wide basis, the working conditions at its warehouses exhibit a marked pattern of local variation. In what follows, we characterize these variations in terms of the three distinct production regimes our field work revealed. To understand these variations requires analysing the social relations at each site. We characterize these regimes as three distinct types: coercive flexibility, hegemonic flexibility, and institutional mutuality. Table 3 provides an overview of the forces that account for the distinct regimes we discerned.

\section{[Table 3 about here]}

\section{Coercive flexibility}

The regimes at Electronics and Food-DE bear a close resemblance to one another; both warehouses have suffered from high levels of scheduling uncertainty as client firms externalize their uncertainties onto the warehouses. We characterize their production regimes in terms of 
coercive flexibility because in both cases, workers lacked the power resources to maintain their autonomy and to resist management's demands, leading to a situation in which working conditions eroded, and high levels of flexibility have been unilaterally imposed on workers.

Electronics' strategy to deal with uncertainty particularly involves using high levels of agency work. The regular agency work quota is at least $50 \%$, which sometimes rises to $70 \%$ to cope with peak volumes. Although $70 \%$ is certainly an exception, the site manager noted that "from time to time, it is handy to be able to use so many agency workers". At Electronics, management's calculus involves a choice between spending more money on employing permanent workers (thereby pleasing workers and the works councilors) versus reducing indirect costs (e.g. sickness pay, HR administration costs) by using agency workers. The operations manager complained: "If someone is sick, we have to pay this person for two entire years. This [practice] costs millions of Euros. Therefore using agency work is convenient to deal with these unforeseeable events."

Although equal pay formally exists between permanent and agency workers, owing to Dutch labor law, using agency work has two major advantages for Electronics, namely cutting back the indicated indirect costs (as the HR manager explained), and retaining a temporally flexible workforce. Agency contracts only guarantee minimum weekly working hours of 20 or 30 hours, which can be extended to 40 hours if demand allows for it. Thus, management at this site views agency work as a strategic source of market flexibility.

Using agency work is the best option for us allowing for both flexibility and controlling our costs. The Netherlands is a rather expensive country as salary levels for skilled people are really high. Based on those levels, we would never win any [business] contract - we cannot compete with Germany or countries in Eastern Europe. Therefore, if we make an offer for warehouse operations including 100 staff, we would always 
calculate based on 50 permanent workers and 50 agency workers. This also provides the necessary flexibility. (Manager for the BeNeLux region)

But the use of agency workers does not only serve economic functions; it also limits the capacity of workers at Electronis to challenge the firm's production regime. Specifically, the majority of agency workers are migrants who are thankful for the opportunity to work at LogisitcsInc, given their weak position in the labor market. Language barriers between the different nationalities make it difficult to create a strong base for solidarity among the workforce, impeding the ability of the local union to get workers engaged or to create a strong base for membership. The native workers, in turn, feel pressured by the well-performing migrant workers. A native worker even expresses doubts on the reasons for hiring migrant workers: "they [management] say that they cannot find Dutch workers - but I don't know if this is true". The pressure stemming from the co-existence of native and migrant workers - in combination with OES - drives the existing high-performance work culture, enabling the firm to implement OES in ways that severely limit employee control. Asked about individual performance measurement, a Dutch worker highlighted that "I feel less free in my work", another one said that "it's like big brother, we are always watched". Even a team leader expressed his understanding of such feelings.

At every second, I can see the location of an employee, what s/he has done so far and what s/he is doing at the very moment. That is going really far. From the side of the company, I see the benefits, as you don't want lazy employees who are chatting with colleagues or do whatever when they should actually work. But it's a mixed blessing. (Dutch team leader, Electronics)

Linked to the high share of migrant workers, there is a relatively low union density at this warehouse, and changes in the Dutch legislation since the early 1990s have allowed for the imposition of à-la-carte regulations in collective agreements, enabling individual employees 
and employers to make certain choices in the employment conditions (Harteveld et al., 2013). In 1999, this development got an institutional push as the Labor Foundation (Ibsen et al., 2018) advocates such steps, allowing for an 'open delegation' clause permitting employers and employees in sites with low union density to reach agreements that undercut the larger workforce's position.

Moreover, the local labor market is no source of power for workers. Although it is relatively tight with other warehouses in the region looking for staff, "the working conditions there are exactly the same", according to a worker (and confirmed by many other workers). Thus, alternative employment would not provide better working conditions. However, this is not because of employer coordination - according to the site manager "there is only one formula to run a warehouse here in a profitable way; by now, everyone in the sector knows this formula".

The conditions at Food-DE resemble those at Electronics; contractual and temporal flexibility are the means to deal with scheduling uncertainty. Agency workers account for a lower but still significant proportion (about 20\%) of the warehouse workforce. Since labor regulations define them as belonging to a different sector than logistics, different administrative rules - i.e. a different sectoral collective agreement - apply. According to the plant manager, agency workers earn 300 to 400 Euros less per month compared to Food-DE's internal workforce; Food-DE uses them for a maximum period of nine consecutive months, as equal pay is legally obligatory afterwards and agency workers "would become too expensive". Several permanent workers reported that only the very best performing agency workers can hope to get a one-year fixed-term contract with Food-DE, while the majority are sent back to the agency at the end of their nine-month stint despite their ambition to get a contract with Food-DE. 
The workforce and their representatives are not in favour of agency work. Workers mentioned issues of fairness and showed solidarity with agency workers while the works council aims at avoiding different working conditions and possible workforce frictions (although no worker reported anything related to this). However, the rather low union presence (among permanent and agency workers) at Food-DE and the lacking veto right on the use of agency work (in the context of co-determination) has prevented workers' representatives from engaging in regulating agency work.

Consequently, the lower use of agency work compared to Electronics does not stem from workers' ability to resist it. Indeed, local management achieved temporal flexibility even with respect to non-agency workers, which the decentralized German context allowed. Specifically, a local collective agreement allows for varying working time in close correspondence with day-to-day levels of product demand. Consequently, employees face sharp variations in their daily working hours ranging between 5 and 10 hours. As the site manager told us:

An employee might work 10 hours on Monday, but only 5 hours on Tuesday. Although the minimum daily working time is 5 hours we can deviate from this regulation by another 3 hours depending on the amount of work. This usually happens when we expect 25.000 picks, but at the end of the week we realize that we only need 15.0000 picks; we can calculate this difference on the working time of every single employee and thus further reduce their hours. (Site manager, Food-DE).

Hence, workers face limited control over their working time. They told us that changes on short notice occur with regularity due to unpredictable fluctuations. Workers' exposure to high levels of scheduling uncertainty also translated into income uncertainty, due to fluctuating wage levels. This local arrangement has inflamed labor-management relations at Food-DE, leading to a prolonged confrontation between workers - represented by the works council - and 
management (a major reason impeding research access). Despite co-determination rights on working time, the works council proved too weak to block the imposition of temporal flexibility, given the decentralized collective bargaining institutions and low union density.

In addition to these institutional forces, the coercive nature of the production regime also reflected local market conditions. The area - a depressed former mining region - is characterized by a marked labor surplus, weakening workers' positions, compelling workers to accept harsh conditions with few if any exit options available. Equally important, however, was Food-DE's market position itself. Food-DE's largest customers regularly provide poor quality information regarding the expected work volumes, externalizing risks onto Food-DE, forcing the warehouse and its entire workforce (i.e. permanent and agency staff) to adjust to market fluctuations with little or no advance notice. But local management had little recourse but to accept such relatively unfavorable contracts - unfavorable not in terms of payment, but in terms of predictability. The clients' greater power in the product market operated to the disadvantage of the workforce, who had to make do with extreme forms of scheduling uncertainty.

We characterize the production regimes at Electronics and Food-DE in terms of coercive flexibility as workers lacked the resources needed to resist, and management was able to unilaterally impose its production demands. In Food-DE, this result seemed to stem from three conditions: the high level of unemployment in the regional labor market, the low predictability regarding orders, and the weakness of worker representation. In this case, the absence of encompassing collective bargaining structures have taken their toll, leading to a downward spiral of worsening working conditions, in turn requiring them to accede to management's demands. Moreover, the derogation from sectoral collective agreements accounts for the weakening of wages and working conditions. Thus, the disadvantageous 
institutional and market forces at play reinforced the weak position of workers in Food-DE, explaining their lack of workplace power.

Similar dynamics engulfed Electronics. Wages and working conditions were not particularly desirable in the region where Electronics is situated, and "the only alternative employment available in the region are other warehouse jobs which provide exactly the same unstable and flexible working conditions" according to a worker. The Dutch collective bargaining system is still relatively centralized, and thus establishes sectoral norms governing wages and working conditions. However, in Electronics, the competition between migrant and non-migrant workers aspiring permanent contracts as well as between agency and permanent workers potentially offsets the workers' power resulting from the relatively beneficial institutional context (when compared to Germany). At the same time, there has been a lack of inclusive solidarity and class identity. Furthermore, the low number and difficulty of getting permanent contracts caused frustration among the workforce and reduced the capacity to organize. According to a worker, it is "generally known that hardly anyone gets a permanent contract, because of the nature of the warehousing business". This latter point was not true across the board, as is shown below.

\section{Hegemonic flexibility}

More favorable circumstances exist at Fashion, since local conditions have led to a different outcome. We term the evolving regime hegemonic flexibility as workers and their representatives could use some power resources to partially neutralize the potentially negative effects of Germany's decentralized and uncoordinated collective bargaining system.

In contrast to Food-DE and Electronics, Fashion has actually reduced its reliance on agency staff, now not exceeding a quota of about $10-15 \%$. On the one hand, this is due to local labor market conditions. Owing to the existing labor shortage within the business park and this 
region of Germany, management has experienced pronounced difficulty recruiting agency workers. On the other hand, the local works council - backed up by higher union density compared to Food-DE - has successfully negotiated limits on the use of agency work, and fostered management's use of permanent contracts as rewards for well-performing agency workers. In effect, Fashion has applied the semblance of an internal labor market rewarding workers for good performance. At the same time, this arrangement limits the danger of generating frictions within the workforce; during informal chats, workers stressed that they see agency staff as colleagues belonging to Fashion; moreover, they supported the policy of offering real employment prospects to them.

These conditions - labor scarcity and higher levels of institutional power - generated power resources for workers, which their representatives in the works council used to negotiate working-time accounts that must be balanced within a time frame of 12 months. In informal chats, workers reported only very limited exposure to fluctuations in their working times (and thus their earnings). As stipulated in the corresponding agreement, workers receive their schedules one month in advance so to adjust it along the workers' family needs. A consensus was also reached that any change on short notice would be rare to avoid confronting workers with sudden clashes between family and work. According to the workers, this normally works out, also because Fashion's client provides high-quality forecasts one month ahead in time. The different tenor of labor relations at Fashion is well represented in the comment of its site manager:

Our requirements are transparent: more hours when there is a lot of work and less hours when there is less. In [month], when there was no work, people voluntarily reduced their overtime, took days off. It works really well. Although it is a new site, the employees are very cooperative and we have a good collaboration with the works council. (Site manager, Fashion) 
Overall then, Fashion is located within an area featuring a labor shortage (labor market forces). It is characterized by relatively predictable work volumes, owing to its ability to bargain with clients from a position of strengths (product market forces). And workers enjoy an established union presence and works council that can wield power in significant ways (institutional forces). Although the uncoordinated nature of the decentralized German collective bargaining system has fostered greater competition between workers at different establishments, at Fashion, the conditions have enabled workers to achieve relatively benevolent treatment, such as real prospects of securing permanent employment, somewhat higher wages, access to training, and other rewards. This also explains why management in Fashion has extended symbolic rewards to workers, for example by regularly providing free food, or organizing staff BBQs in the summer. Workers seem to have appreciated those actions and feel rewarded, and according to Fashion's local manager, "such actions are not expensive, but provide an added value for our employees" supporting worker hiring and retention within a tight labor market where firms must compete to recruit and retain their workers.

The resulting regime is characterized by a workforce using its power resources; in turn, management has secured its workforce's consent by making concessions to workers' needs. We refer to this regime as hegemonic flexibility, which reflects institutional and market forces conducive to workers' ability to exert control at work. As a result, and by threatening 'exit', workers and their representatives at Fashion have to some extent neutralized the potentially negative effects of Germany's decentralized and uncoordinated collective bargaining system. Thus, we find sharp differences between Food-DE and Fashion despite their embeddedness in the same institutional context; we attribute this variation to the disparate product and labor market conditions impinging on the two sites.

\section{Institutional mutuality}


The conditions at Food-BE, the Belgian site, are again quite distinct because of the institutional and labor market conditions the workforce encounters. With respect to the former, Belgian law dictates that workers employed on different contracts be accorded equal treatment in terms of wages, and the high union density at Food-BE enables workers to exercise their voice more effectively than at the other sites. The result is the most favorable regime; we label it institutional mutuality.

As volumes are relatively predictable, the flexibility workers are required to provide is manageable, particularly in comparison with Food-DE and Electronics. In Food-BE, a maximum of 30 to 40 agency workers (maximum 15\%) are used to accommodate fluctuations in peak periods. Since equal provisions are not only stipulated by law but also closely monitored by the strong local unions at this highly unionized warehouse, agency workers are not cheaper than permanent workers; this discourages their use and reduces the risk of fissuring solidarity among the workforce. Therefore, management accedes to the workers and unions' request not to use a high number of agency workers, which makes workforce friction less likely. In return, the workers and their representatives accommodate management to some extent, reciprocating by agreeing to flexibility requests when business needs warrant the use of agency work. Workers are also willing to provide some working time flexibility if needed within clearly defined limits. Specifically, workers can be asked to work 1 to 2 paid hours more per day, but can easily say no if the extra hours would for instance clash with family obligations. A team leader explains that "we sometimes need to work longer or start earlier to achieve the targeted number of picks to keep the customer satisfied; yet, nobody is forced to do so, we just ask who could start earlier or stay longer". The voluntary nature of working overtime is confirmed by an order picker who told us that "I worked additional hours only two or three times last year". 
Most of the employees are aware that their performance is measured and evaluated in the weekly one-to-one talks with team leaders. Although some workers highlight the negative effects of individual performance measurement on collaboration, this does not lead to tensions since -in a context that seems to minimize the threats workers might otherwise face-- workers generally regard performance reports as a form of feedback from the team leader on how to improve. Several workers spoke of feeling gratified when the team leader recognized the good job they have done as signs of their of commitment and loyalty to LogisticsInc.

Interviews with workers reveal that fulfilling hourly target numbers works smoothly on days with a low to normal workload but that achieving this target at peak times can be challenging. Yet, an order picker explained (and this was confirmed by others): "I simply take the time I need to finish an order. I will not accelerate as this may endanger the quality of my work". At times with high workload, team leaders adopt effective strategies for the assignment of tasks and revealingly, and these presuppose the presence of high levels of trust among their subordinates. For example, when orders are tight, team leaders often opt to assign orders to their most competent employees, to make sure that the volumes can be handled and that the production flow proceeds smoothly. A team leader in Food-BE describes this latter approach simply by stating that "performance levels differ between employees". But the more skilled employees notice such a strategy, and are aware that less skilled workers are being told not to take "the orders on top of the pile, but look through the whole papers and select simple orders" (order picker, Food-BE). In effect, such a system requires a greater work effort from the more skilled workers, who must tacitly agree to such terms. We view such practices as a sign that local management has been able to establish a reservoir of trust, eliciting cooperation and sacrifice for the sake of all workers, and for the facility as a whole.

When asked about how management used the performance tracking system, few expressed any fear that low performing workers would be at risk of poor evaluations or, worse, 
be threatened with discipline or termination. The majority were keen to know about the warehouse's overall performance and its ability to satisfy the clients, which they regarded as the best way to keep the site alive and consequently safeguard their jobs. For example, one reacher told us: "You want to know what is really important for me in my job? Well, it is important that at the end of each day, all work has been done and the customer is happy about us and our performance."

One may expect that the relatively high union density, encompassing collective bargaining structures (institutional forces), along with stable and predictable product demands and relatively low levels of unemployment within the local labor market (market forces) constitute resources workers could use to leverage their workplace power as their capacity to exercise control over work, challenging the production regime itself. Our findings, however, illustrate that Food-BE's workforce did not use its 'latent' power as a weapon for resisting management's demands or seeking better working conditions. This does not even seem to be an option for them because (as an order picker put it; and this was highlighted by the majority of workers) "for me, the customer is the king, I want the customer to be satisfied". However how stable this arrangement may be, management and workers have found ways to conjoin their interests, much in keeping with Wright's (2000) notion of a "positive class compromise." Workers are not making concessions to management from a position of weakness, but out of strength. Both workers and LogisticsInc have found benefit in the regime that has emerged, and tacitly agreed to limit the claims they make upon one another.

\section{Discussion}

In this paper we have focused on the logistics sector, which holds increasing centrality in an era of global capitalism. Although this sector has attracted attention from scholars concerned with the distribution of power within global value chains (Cowen, 2014; Chua et al., 2018; 
Sowers, 2017; Bonacich \& Wilson 2008), the resulting research has often tended to homogenize the nature of production politics and their outcomes at the workplace level. For example, current studies in warehouses illustrate how management relies largely on coercive practices and policies, which in turn may emphasize the despotic nature of work at varying points in the logistics circuits, as Newsome et al. (2013) conclude regarding warehouses in Britain. We rather observe a pattern of substantial variation in production regimes across cases, which we view as extending Burawoy's (1985) original theory of factory regimes via the use of kindred approaches (notably, Wright's (2000) theory of class compromises).

The warehouses in our study are owned by the same logistics firm and have introduced the same system of lean logistics, which requires all warehouses to institute similar practices for coordination by standardizing and monitoring the workforce. Yet, much as in Gallie's (1978) cross-national study, in which institutional variations overruled the effects of production technology, we find sharp variations in the production regimes that nonetheless obtain in different locales. These seem to flow from differences in the power resources that workers are able to amass. Two such sources of variation emerge as especially important: institutional conditions (the associational power of trade unions and the collective agreements they have established) and market forces (stemming from labor and product markets). As shown, where the warehouse holds a weak position in relation to its customers, it must accept unfavorable terms, which it then passes on workers, for example in the form of temporal flexibility. Finally, although theorists have suggested that organizational power, rooted in the technical features of the labor process, can provide a potentially important resource for workers, we find little evidence of such an effect. ${ }^{2}$ Variations in production regimes are, it seems, highly pronounced

\footnotetext{
${ }^{2}$ Arguably, such organizational forces have been flattened out by the firm's pursuit of uniformity via OES and lean management. This is a matter for further empirical research.
} 
even within the same logistics firm seeking to standardize its internal operations, and these stem largely from market and institutional forces beyond management's control.

We have raised questions about the adequacy of Burawoy's original theory for its relatively underdeveloped rendering of the production regimes that workers confront in the advanced capitalist world. Yet, his conception of 'hegemonic despotism' manages to capture the conditions of at least some of our sites, if inexactly. At Fashion, workers wield just enough power resulting from labor and product market forces to make management pursue ways of gaining the consent of its workforce to its flexibilization campaign (hegemonic flexibility). These conditions successfully limit workforce fragmentation which could result from the institutional weaknesses which the uncoordinated and decentralized German collective bargaining system often invites. By contrast, in the other German site (Food-DE), and to a lesser extent in the Dutch site (Electronics), management was able to capitalize on the workers' weak institutional and market position, imposing a type of production regime we have called coercive flexibility. Here, management took advantage of the workers' vulnerability, unilaterally imposing on them a harsh set of working conditions that workers had no recourse but to accept. Conversely, where workers enjoy the most favourable combination of power resources deriving from both institutional and market forces (Food-BE in Belgium), what emerges is a regime in which the asymmetrical nature of the wage labor relation is largely subdued or suppressed. On the other hand, we observe that under these conditions it is more difficult for management to fragment the workforce, and a relation approximating institutional mutuality is achieved.

LogisticsInc has sought to achieve not only maximum flexibility throughout its geographically dispersed warehouses but also to standardize their internal operations, using its lean-derived OES to maximise the level of work intensity and thus, profits. Yet, the logic of this study suggests that its efforts are likely to meet with a varied reception across its various 
locations. The reason stems not only from local labor and product market variations but also from differences in the institutional and associational power that workers are able to deploy, which in turn affect the exercise of class power. Indeed, the very establishment of a global logistics system is likely to only multiply the disparities found within the system, as firms like LogisticsInc encompass localities facing widely different conditions of production. Whether the firm will be able to manage the resulting contradictions remains to be seen.

\section{Conclusions}

This comparative study on warehouses has shown that where workers enjoy a confluence of favorable conditions, they are at times able to extract compromises from their employers, generating production regimes that are distinctly different from those encountered under worse conditions. Thus, the study contributes to debates on theories of management practices and policies, and workers' responses in the growing service industries. Conversely from AngloSaxon perspectives emphasizing the presence of hegemonic elements in warehousing, we have identified and explained a diverse array of patterns highlighting substantial variation in production regimes. This is at the core of the theoretical and analytical contribution of this study i.e. to develop a typology of production regimes by identifying ideal types, and to examine the factors shaping variation in these regimes.

Our typology of production regimes sets some directions for future research by providing an analytical framework for the systematization and examination of managementlabor relations in logistics. Moreover, there are also theoretical implications. Within a context marked by the rise of e-commerce, increasing competition between giant retailers like Amazon and Alibaba, and opposition to trade unions and collective agreements regulating the terms and conditions of employment, our cases may seem to be increasingly exceptional. Whether this is so, and whether logistics workers can begin to build institutional strengths capable of 
transcending local variations in their work situations, remain indeed important matters for future research. Especially in an era marked by risk and crises of various sorts, it will be increasingly important to understand the work situations of logistics workers and the conditions that affect their willingness to comply with the production regimes that govern the global supply chains on which our lives now depend.

\section{References}

Allen, W.B. (1997). The Logistics Revolution and Transportation. The ANNALS of the American Academy of Political and Social Science, 553(1), 106-116.

Alimahomed-Wilson, J. \& Ness, I. (2018). Choke Points: Logistics Workers Disrupting the Global Supply Chain. Pluto Press: London.

Basso, P. (2015). Neoliberalism, Crisis and International Migration. In: L. Pradella, T. Marois (Eds.) Polarising Development (pp. 86-97). Pluto: London.

BCG (2016). Transportation and logistics in a changing world. Available from https://www.bcg.com/publications/2016/corporate-development-finance-value-creationstrategy-transportation-and-logistics-in-a-changing-world.aspx [Cited 2019 May 22].

Bélanger, J. \& Edwards, P. (2007). The conditions promoting compromise in the workplace. British Journal of Industrial Relations, 45(4), 713-734.

Belgian National Bank (2017). Economic importance of the logistics sector in Belgium. Available from https://www.nbb.be/doc/ts/publications/wp/wp325en.pdf [Cited 2019 May 22].

Benvegnú, C., Haidinger, B., \& Sacchetto, D. (2018). Restructuring Labor Relations and Employment in the European Logistics Sector. Unions' Responses to a Segmented Workforce. In: V. Doellgast, N. Lillie, \& V. Pulignano (Eds.) Reconstructing Solidarity. 
Labor Unions, Precarious Work, and the Politics of Institutional Change in Europe (pp. 83104). Oxford University Press: Oxford.

Bonacich, E. \& Wilson, J. (2008). Getting the Goods: Ports, Labor, and the Logistics

Revolution. Ithaca: Cornell University Press.

Brown, W. (2008). The Influence of Product Markets on Industrial Relations. In P. Blyton, E. Heery, N. Bacon, \& J. Fiorito (Eds.) The SAGE Handbook of Industrial Relations (pp. 113128). London: SAGE.

Burawoy, M. (1979). Manufacturing Consent. The University of Chicago Press: Chicago.

Burawoy, M. (1985). The politics of production. London: Verso.

Burawoy, M. \& Wright, E. O. (1990). Coercion and Consent in Contested Exchange. Politics \& Society, 18(2), 251-266.

BVL (2018). Logistikumsatz und Beschäftigung. Available from https://www.bvl.de/service/zahlen-daten-fakten/umsatz-und-beschaeftigung [Cited 2019 May 22].

Chua, C. (2014). Logistics, Capitalist Circulation, Chokepoints. Available from https://thedisorderofthings.com/2014/09/09/logistics-capitalist-circulation-chokepoints/ [Cited 2019 July 29].

Chua, C., Danyluk, M., Cowen, D., \& Khalili, L. (2018). Introduction: Turbulent Circulation: Building a Critical Engagement with Logistics. Environment and Planning D: Society and Space, 36(4), 617-629.

Cillo, R., \& Pradella, L. (2018). New immigrants' struggles in Italy's logistics industry. Comparative European Politics, 16(1), 67-84.

Cini, L. \& Tassinari, A. (2018). On Struggles in Logistics: Notes for militant labor activism from the Italian experience. Available from https://notesfrombelow.org/article/struggleslogistics-notes-militant-labor-activism [Cited 2019 July 29]. 
Council of Logistics Management (2019). CSCMP Supply Chain Management Definitions and Glossary.

Available from https://cscmp.org/CSCMP/Educate/SCM_Definitions_and_Glossary_of_Terms/CSCMP/E ducate/SCM_Definitions_and_Glossary_of_Terms.aspx?hkey=60879588-f65f-4ab5-8c4b6878815ef921 [Cited 2019 May 22].

Cowen, D. (2014). The Deadly Life of Logistics. Mapping Violence in Global Trade. Minneapolis: University of Minnesota Press.

De Vaus, D. (2001). Research Design in Social Research. Sage: London.

Doellgast, V., Lillie, N., \& Pulignano, V. (2018). Reconstructing Solidarity. Labor Unions, Precarious Work, and the Politics of Institutional Change in Europe. Oxford University Press: Oxford.

Dutch Ministry of Economic Affairs (2014). Made in Holland - Logistics. Available from https://china.investinholland.com/wp-content/uploads/2015/05/Made-in-HollandLogistics.pdf [Cited 2019 May 22].

Eisenhardt, K. (1989). Building Theories from Case Study Research. The Academy of Management Review, 14(4), 532-550.

Gallie, D. (1978). In Search of the New Working Class. Cambridge: Cambridge University Press.

Haidinger, B., Schönauer, A., Flecker, J., \& Holtgrewe, U. (2014). Value Chains and Networks in Services: Crossing Borders, Crossing Sectors, Crossing Regimes? In M. Vidal \& M. Hauptmeier (Eds.) The Comparative Political Economy of Work and Employment Relations (pp. 98-118). London: Palgrave Macmillan.

Hall, P.A. \& Soskice, D. (2001). Varieties of Capitalism: The Institutional Foundations of Comparative Advantage. Oxford: Oxford University Press. 
Hancké, B. Rohdes, M. \& Thacher, M. (2007). Beyond Varieties of Capitalism. Oxford University Press: Oxford.

Harvey, M. (2018). Competition as instituted economic process. In S. Metcalf \& A. Warde (eds.), Market relations and the competitive process. Manchester: Manchester University Press.

Holst, H., \& Singe, I. (2017). Arbeiten in Parallelwelten - Externalisierung und Informalisierung von Arbeit in der Paketzustellung. In: H. Holst (Eds.) Fragmentierte Belegschaften. Leiharbeit, Informalität und Soloselbständigkeit in globaler Perspektive (pp. 165-190). Frankfurt am Main: Campus.

Huke, N., Clua-Losada, M., \& Bailey, D. (2015). Disrupting the European Crisis: A Critical Political Economy of Contestation, Subversion and Escape. New Political Economy, 20(5), $725-751$.

Katz, H. \& Darbishire O. (2000). Converging Divergences. Ithaca: Cornell University Press.

LeCavalier, J. (2016). The Rule of Logistics: Walmart and the Architecture of Fulfillment. Minneapolis: University of Minnesota Press.

Lichtenstein, N. (2009). The Retail Revolution: How Wal-Mart Created a Brave New World of Business. New York: Picador.

Newsome, K. (2010). Work and employment in distribution and exchange: Moments in the circuit of capital. Industrial Relations Journal, 41(3), 190-205.

Newsome, K., Thompson P., \& Commander J. (2013). You monitor performance at every hour: Labor and the management of performance in the supermarket supply chain. New Technology, Work and Employment, 28(1), 1-15.

Neilson, B. (2012). Five theses on understanding logistics as power. Distinktion: Journal of Social Theory, 13(3), 322-339. 
Palier, B. \& Thelen, K. (2010). Institutionalizing Dualism: Complementarities and Change in France and Germany. Politics \& Society, 38(1), 119-148.

PwC (2016). Shifting patterns. The future of the logistics industry. Available from https://www.pwc.com/sg/en/publications/assets/future-of-the-logistics-industry.pdf [Cited 2019 May 22].

Rueda, D. (2014). Dualization, crisis and the welfare state. Socio-Economic Review, 12(2), $381-407$.

Sainato, M. (2020). I'm not a robot: Amazon workers condemn unsafe, gruelling conditions at warehouse. Available from https://www.theguardian.com/technology/2020/feb/05/amazon-workers-protest-unsafegrueling-conditions-warehouse [Cited 2020 February 5].

Sallaz, J. (2019) Lives on the Line: How the Philippines Became the World's Call Center Capital. Oxford: Oxford University Press.

Schmalz, S., Ludwig, C., \& Webster, E. (2018). The Power Resources Approach: Developments and Challenges. Global Labor Journal, 9(2), 113-134.

Selwyn, B. (2012). Workers, State and Development in Brazil: Powers of Labor, Chains of Value. Manchester: Manchester University Press.

Silver, B. (2003). Forces of Labor: Workers' Movement and Globalization since 1870. New York: Cambridge University Press.

Sowers, E. (2017). Logistics Labor: Insights from the Sociologies of Globalization, the Economy, and Work. Sociology Compass, DOI 10.1111/soc4.12459.

Sowers, E., Ciccantell, P. \& Smith, D. (2018). Labor and Social Movements' Strategic Usage of the Global Commodity Chain Structure. In J. Alimahomed-Wilson \& I. Ness (Eds.) Choke Points: Logistics Workers Disrupting the Global Supply Chain (pp.19-34). Pluto Press: London. 
Statista (2020). Gross revenue generated by the US third party logistics industry from 2000 to 2018. Available from https://www.statista.com/statistics/638368/us-third-party-logisticsmarket/ [Cited 2020 March 10].

Vallas, S. (1999). Re-thinking Post-Fordism: The Meanings of Workplace Flexibility. Sociological Theory, 17(1), 68-101.

Vallas, S. (2003). The Adventures of Managerial Hegemony: Ideology, Teams, and Worker Resistance. Social Problems, 50(2), 204-225.

Vallas, S. (2006). Empowerment Redux: Structure, Agency, and the Re-Making of Managerial Authority. American Journal of Sociology, 111(6), 1677-1717.

Vallas, S. \& Hill, A. (2012). Conceptualizing Power in Organizations. In D. Courpasson, D. Golsorkhi, \& J. Sallaz (Eds.) Rethinking Power in Organizations, Institutions, and Markets (Research in the Sociology of Organizations, Volume 34) (pp. 165-197). Binkley: Emerald. Yin, R. (2018). Case Study Research and Applications. London: Sage.

Weil, D. (2014). The fissured workplace. Cambridge: Havard University Press.

Wright, E. (2000). Working-Class Power, Capitalist-Class Interests, and Class Compromise. American Journal of Sociology, 105(4), 957-1002.

Zanker, K. (2018). Branchenanalyse Logistik. Der Logistiksektor zwischen Globalisierung, $\begin{array}{llll}\text { Industrie } & 4.0 \quad \text { und } & \text { Online-Handel. } & \text { Available from }\end{array}$ https://www.boeckler.de/pdf/p_study_hbs_390.pdf [Cited 2019 February 15].

Nadja Dörflinger is a senior scientist in the Research Group 'Changing World of Work' at Germany's Federal Institute for Occupational Safety and Health. Her mostly comparative research focuses primarily on labour market segmentation and fragmentation, as well as flexibility and security in European labour markets. 
Valeria Pulignano is Professor of Sociology at KULeuven, Belgium. Her research is comparative and it focuses on labour market institutions, flexibility, and employment systems and their impact on job quality, inequality, workers' voice. She is granted a recent ERC AdvancedGrant (ResPecTMe) studying precariousness in digital, creative, and care workplaces.

Steven Vallas is Professor of Sociology at Northeastern University, Boston. Most of his research concerns the transformation of work, struggles over new technologies, and responses to the demands of the new economy. He is currently at work on an NSF-funded study of the algorithmic workplace, as found in various parts of the platform economy. 


\section{Figure 1: Different forces and sources of power}

Institutional forces

Workers' associational power drawing on collective organization and labour relations institutions that impinge on each warehouse
Market forces

Marketplace (structural) bargaining power consists of labour market forces (tightness of the labour market) and product market forces (the predictability of volumes)

\section{Organizational forces}

Workplace (structural) bargaining

power resulting from the possible leverage created by the workers' strategic resources

$\rightarrow$ Power resources translate into the capacity of workers to exercise control; the combination of forces and power resources

shapes different production regimes 
Table 1: Case and country features

\begin{tabular}{|c|c|c|c|c|}
\hline & Electronics (NL) & Food-DE & Fashion (DE) & Food-BE \\
\hline \multicolumn{5}{|l|}{$\begin{array}{l}\text { Warehouse } \\
\text { characteristics }\end{array}$} \\
\hline $\begin{array}{l}\text { Internal workforce } \\
\text { (permanent and } \\
\text { temporary contracts) }\end{array}$ & Ca. 300 & Ca. 150 & Ca. 300 & Ca. 250 \\
\hline Agency workers & $\begin{array}{c}300 \\
(\text { ca. } 50 \%)\end{array}$ & $\begin{array}{c}30 \\
(\text { ca. } 20 \%)\end{array}$ & $\begin{array}{c}30-45 \\
\text { (ca. } 10-15 \%)\end{array}$ & $\begin{array}{c}30-40 \\
(\text { ca. } 15 \%)\end{array}$ \\
\hline Products & $\begin{array}{c}\text { Consumer } \\
\text { electronics, office } \\
\text { devices }\end{array}$ & Food & Fashion & Food \\
\hline Number of clients & More than 1 & More than 1 & 1 & More than 1 \\
\hline Start of operations & $\begin{array}{l}\text { About } 10 \text { years } \\
\text { ago }\end{array}$ & $\begin{array}{c}\text { More than } 20 \\
\text { years ago }\end{array}$ & $\begin{array}{l}\text { Less than } 5 \\
\text { years ago }\end{array}$ & $\begin{array}{l}\text { More than } 20 \\
\text { years ago }\end{array}$ \\
\hline \multicolumn{5}{|l|}{ Institutional features } \\
\hline Trade union density* & $17.3 \%$ & \multicolumn{2}{|c|}{$17 \%$} & $54.2 \%$ \\
\hline $\begin{array}{l}\text { Collective bargaining } \\
\text { coverage* }\end{array}$ & $78.6 \%$ & \multicolumn{2}{|c|}{$56 \%$} & $96 \%$ \\
\hline $\begin{array}{l}\text { Degree of } \\
\text { centralization** }\end{array}$ & $\begin{array}{l}\text { Centralised and } \\
\text { rather coordinated }\end{array}$ & \multicolumn{2}{|c|}{ Uncoordinated and decentralised } & $\begin{array}{l}\text { Coordinated } \\
\text { and centralised }\end{array}$ \\
\hline
\end{tabular}

Table 2: Overview of formal interviews and observations

\begin{tabular}{|l|l|l|l|}
\hline \multicolumn{4}{|l|}{ Number of formal interviews and observations } \\
\hline $\begin{array}{l}\text { International and } \\
\text { national trade union } \\
\text { experts }\end{array}$ & $\begin{array}{l}7 \text { interviews } \\
3 \text { trade union meetings }\end{array}$ & \multicolumn{2}{l|}{} \\
\hline & Management & Workers & Ethnography \\
\hline Headquarters & 5 & $/$ & $\begin{array}{l}\text { day (annual } \\
\text { shareholder meeting) }\end{array}$ \\
\hline Food-BE & 4 & 15 & 3 days \\
\hline Electronics (NL) & 5 & 20 & 3 days \\
\hline Fashion (DE) & 2 & 3 & 1 day \\
\hline Food-DE & 2 & 2 & 1 day \\
\hline Total & 18 & 35 & 9 days \\
\hline $\begin{array}{l}\text { Total number of formal } \\
\text { interviews }\end{array}$ & 60 interviews, 9 days of observation, 3 trade union meetings \\
\hline
\end{tabular}


Table 3: Power resources and production regimes at warehouses

\begin{tabular}{|c|c|c|c|c|}
\hline & Electronics (NL) & Food-DE (DE) & Fashion (DE) & Food-BE (BE) \\
\hline $\begin{array}{l}\text { Institutional } \\
\text { forces } \\
\text { (Associational } \\
\text { Power) }\end{array}$ & $\begin{array}{l}\text { Low } \\
\text { Low union density; } \\
\text { decentralized but relatively } \\
\text { coordinated nature of multi- } \\
\text { employer bargaining allowing for } \\
\text { 'open delegation clauses' }\end{array}$ & $\begin{array}{l}\text { Low } \\
\text { Low union density; works council } \\
\text { has extensive co-determination } \\
\text { rights; multi-employer bargaining } \\
\text { structures but derogation } \\
\text { possibilities from sectoral } \\
\text { agreements and possibility to opt } \\
\text { out of collective bargaining }\end{array}$ & $\begin{array}{l}\text { Low } \\
\text { Slightly higher union density than } \\
\text { in Food-DE; works council has } \\
\text { extensive co-determination rights; } \\
\text { multi-employer bargaining } \\
\text { structures but derogation } \\
\text { possibilities from sectoral } \\
\text { agreements and possibility to opt } \\
\text { out of collective bargaining }\end{array}$ & $\begin{array}{l}\text { High } \\
\text { Relatively high union density in the } \\
\text { workplace; centralized multi- } \\
\text { employer bargaining structures } \\
\text { with low derogation possibilities }\end{array}$ \\
\hline $\begin{array}{l}\text { Market-based } \\
\text { forces } \\
\text { (Marketplace } \\
\text { bargaining } \\
\text { power) }\end{array}$ & $\begin{array}{l}\text { Low } \\
\text { Low to medium level of product } \\
\text { market predictability; relatively } \\
\text { tight labor market }\end{array}$ & $\begin{array}{l}\text { Low } \\
\text { Highly unpredictable product } \\
\text { market; labor market not tight at all }\end{array}$ & $\begin{array}{l}\text { High } \\
\text { Highly predictable product market; } \\
\text { tight labor market }\end{array}$ & $\begin{array}{l}\text { Medium } \\
\text { Relatively predictable product } \\
\text { market; relatively tight labor } \\
\text { market }\end{array}$ \\
\hline $\begin{array}{l}\text { Organizational } \\
\text { forces } \\
\text { (Workplace } \\
\text { bargaining } \\
\text { power) }\end{array}$ & $\begin{array}{l}\text { Low } \\
\text { High levels of flexibility are } \\
\text { imposed on workers who lack } \\
\text { power resources to resist }\end{array}$ & $\begin{array}{l}\text { Low } \\
\text { High levels of flexibility are } \\
\text { imposed on workers who lack } \\
\text { power resources to resist }\end{array}$ & $\begin{array}{l}\text { Medium } \\
\text { Workers could negotiate a } \\
\text { relatively benevolent treatment and } \\
\text { management secured consent by } \\
\text { making concessions to workers' } \\
\text { needs }\end{array}$ & $\begin{array}{l}\text { High } \\
\text { Workers could use substantial } \\
\text { power resources to reach a } \\
\text { compromise reflecting the interests } \\
\text { of both parties }\end{array}$ \\
\hline $\begin{array}{l}\text { Production } \\
\text { regime }\end{array}$ & Coercive flexibility & Coercive flexibility & Hegemonic flexibility & Institutional mutuality \\
\hline
\end{tabular}

